\title{
EFFECT OF FLUORINE IN THE SYNERGISM Co-Mo VIA HYDROGEN SPILLOVER ON THE HYDRODESUL- PHURIZATION OF REFRACTORY MOLECULES
}

\author{
A. MÉNDEZ1', M. VILLARROEL ${ }^{2}$, E. CAMÚ', F.J. GIL-LLAMBÍAS', P. ÁVILA', P. BAEZA ${ }^{1}$ \\ ${ }^{1}$ Pontificia Universidad Católica de Valparaíso, Casilla 4059, Valparaíso, Chile. \\ ${ }^{2}$ Universidad Católica Silva Henríquez, General Jofré 462, Santiago, Chile. \\ ${ }^{3}$ Universidad de Santiago de Chile, Facultad de Química y Biología, Casilla 40, Correo 33, Santiago, Chile. \\ ${ }^{4}$ Instituto de Catálisis y Petroleoquímica, Consejo Superior de Investigación Científica, ICP, CSIC España.
}

(Received: July 30, 2013 - Accepted: August 30, 2013)

\begin{abstract}
The influence of fluorine concentration on the synergism between $\mathrm{Co} / \gamma-\mathrm{Al}_{2} \mathrm{O}_{3}$ and $\mathrm{Mo} / \gamma-\mathrm{Al}_{2} \mathrm{O}_{3}$ stacked beds separated by $3-\mathrm{mm}_{\mathrm{m}}$ of $\gamma-\mathrm{Al}_{2} \mathrm{O}_{3} \mathrm{~F}_{\mathrm{x}}(\mathrm{x}=0-2.5 \%)$, in the hydrodesulphurization of refractory molecules contained in gasoil, under operating conditions similar to those of industry, was studied. The results shown, that the synergism increases with F content, reaching a maximum at $0.8 \%$ of fluorine, which it is related to changes in zero point of charge (ZPC) and acid strength, due to the incorporation of fluorine. The conversion of most refractory molecule reported is favoured by fluorine.
\end{abstract}

Keywords: Hydrodesulphurization, Fluorine, Stacked Bed, Synergism.

\section{INTRODUCTION}

At the present, environmental regulations are becoming more stringent in relation to maximum levels of sulphur allowed in diesel, increasing the interest in more efficient systems, in order to obtain fuels that meet the standards. This, coupled with the need to exploit petroleum fractions which have a greater amount of refractory sulphur compounds, and the use of products derived from petroleum that will remain the main energy source, have renewed efforts to develop new catalysts for hydrodesulphurization (HDS) ${ }^{1}$.

In the conventional $\mathrm{Co}-\mathrm{Mo} / \gamma-\mathrm{Al}_{2} \mathrm{O}_{3} \mathrm{HDS}$ catalysts, the activity of $\mathrm{MoS}_{2}$ is promoted by the presence of $\mathrm{Co}$, producing a synergetic effect. This effect has been explained principally through two models, the Co-Mo-S ${ }^{2}$ and the Remote Control model ${ }^{3}$. In our research group, the synergisms has been studied in experimental conditions in which only operated the remote control mode ${ }^{4-11}$, that postulates that synergism is caused by the formation of an activated hydrogen specie called "hydrogen spillover" (Hso) in the Co sulphide surface, which migrates to the $\mathrm{MoS}_{2}$, increasing the amount of its active sites, without formation of any mixed phases like Co-Mo-S ${ }^{12}$

To meet the environmental specifications are required new catalysts that offer better activity and selectivity for hydrodesulphurization of sulphur refractory compounds -known as deep HDS-, and have greater tolerance to sulphur. It is for this reason that various additives have been studied for HDS catalysts and one of them is fluorine. In this respect, it have pointed out that the effect on the catalytic activity of the addition of fluorine to the catalyst is varied and complex, and depends on the type of reaction, the reaction temperature, the fluorine content, and also the order of addition of the promoter ${ }^{13,14}$. Additionally, it was noted that the incorporation of fluorine change Mo dispersion ${ }^{15,16}$, and by varying the content of fluorine, synergism increases, passing through a maximum, attributed to the modification of the surface coating of the active phase $^{17-21}$

In the publication by C. Kwak et al. ${ }^{22}$ is studied the HDS of three molecules: dibenzothiophene (DBT), 4-methyldibenzothiophene (4-MDBT) and 4,6-dimethyldibenzothiophene (4,6-DMDBT), based on three basic reactions involved in the mechanism of the HDS: hydrogenation of aromatic ring, hydrogenolysis of the $\mathrm{C}-\mathrm{S}$ bond, and the migration of methyl groups on the ring structure, using Co-Mo-S $/ \gamma-\mathrm{Al}_{2} \mathrm{O}_{3} \mathrm{~F}_{\mathrm{x}}$ catalysts (where $\mathrm{x}=0.0-2.5 \%$ ), concluding that the addition of fluorine to Co-Mo catalyst promotes all these reactions, mainly due to the improvement in the dispersion of metal and acidity that fluorine would give to the catalyst. The degree of enhancement of the activity by addition of fluorine increases in the order of DBT $<4$-MDBT $<4,6$-DMDBT. In another study, by H. Kim et al. ${ }^{23}$, was tested the competitive effect of a feed doped with basic nitrogen compounds as Quinoline and non-basic as Carbazole, during the HDS of DBT and 4,6-DMDBT for Ni-Mo/ $\gamma-\mathrm{Al}_{2} \mathrm{O}_{3} \mathrm{~F}_{\mathrm{x}}$ catalysts, observing an increase in activity for the fluorinated catalysts compared to non-fluorinated, it was also found that this increase was achieved for the feeds also doped with nitrogenous compounds, although this activity and the distribution of reaction products changed depending upon the combination of reactants DBT, 4,6-DMDBT and impurities, making reference that, although the path suppresses Quinoline HYD, for the most refractory molecule investi- gated (4,6-DMDBT) the incorporation of fluorine favors the HDS by this route. Also was published ${ }^{24,25}$, on which noted the fluorine as additive, given that favor the HDS of refractory molecules due to its ability to increase the acidity of the catalyst, as well as by the increased dispersion of the metal in the support. Furthermore, it is mentioned that the incorporation of fluorine into the catalyst has a positive effect on the activity of HDS, HDN, and hydrogenation, depending upon the amount of and catalyst preparation procedures. It should be noted however, that the use of fluorine in HDS catalysts, have been studies only on Co-Mo bimetallic catalysts in which Co-Mo-S phase can be present, but there are no studies on the effect of fluorine on the Co-Mo synergism in absence of Co-Mo-S phase.

Consequently, the aim of this study was studied the effect of the addition of fluorine in the separator, on HDS of refractory molecules in Co-Mo bimetallic catalysts, but using as model a $\mathrm{Co} / \gamma-\mathrm{Al}_{2} \mathrm{O}_{3}$, as metal donor of $\mathrm{Hso}\left(\mathrm{M}_{\mathrm{D}}\right)$ and $\mathrm{Mo} / \gamma-\mathrm{Al}_{2} \mathrm{O}_{3}$, as acceptor of Hso $\left(\mathrm{M}_{\mathrm{A}}\right)$ in a stacked beds systems to avoid the formation of Co-Mo-S phase.

\section{EXPERIMENTAL}

\subsection{Preparation of samples and catalysts.}

Samples were prepared using $\mathrm{Co}\left(\mathrm{NO}_{3}\right)_{2} * 6 \mathrm{H}_{2} \mathrm{O}$ and $\left(\mathrm{NH}_{4}\right)_{6} \mathrm{Mo}_{7} \mathrm{O}_{24} * 4 \mathrm{H}_{2} \mathrm{O}$ (Merck p.a.) as precursors salts, $\gamma-\mathrm{Al}_{2} \mathrm{O}_{3}$ BASF D10-10 (N, BET $212 \mathrm{~m}^{2} \mathrm{~g}^{-1}$ and pore volume $0.500 \mathrm{~cm}^{3} \mathrm{~g}^{-1}$ ) was used as support and $\mathrm{SiO}_{2}$ BASF D11-10 (BET $154 \mathrm{~m}^{2} \mathrm{~g}^{-1}$ and pore volume $0.270 \mathrm{~cm}^{3} \mathrm{~g}^{-1}$ ) was used for diluting the $\mathrm{Mo} / \gamma-\mathrm{Al}_{2} \mathrm{O}_{3}$ bed.

The $\mathrm{Co} / \gamma-\mathrm{Al}_{2} \mathrm{O}_{3}$ and $\mathrm{Mo} / \gamma-\mathrm{Al}_{2} \mathrm{O}_{3}$ catalysts were prepared by impregnation in excess of solvent using a rotary evaporator as in previous studies ${ }^{4-11}$. Once impregnated the samples were dried at $373 \mathrm{~K}$ for $12 \mathrm{~h}$ and calcined at $823 \mathrm{~K}$ for $4.5 \mathrm{~h}$. The nominal metal contents are close to 1.6 atoms $\mathrm{nm}^{-2}$ for Co and 2.9 atoms $\mathrm{nm}^{-2}$ for Mo.

Alumina impregnated with fluorine, $\gamma-\mathrm{Al}_{2} \mathrm{O}_{3} \mathrm{~F}_{x}$ (where $\mathrm{x}=0.0,0.2,0.8,1.5$ or $2.5 \%$ ), was prepared as previously described ${ }^{26}$ using a $\mathrm{NH}_{4} \mathrm{~F}$ aqueous solution with the appropriate concentration of fluorine for render the fluorine load in each samples. This solution was heated at $373 \mathrm{~K}$ and then added to alumina previously heated for 2 hours in an oven at $283 \mathrm{~K}$. The impregnated and wet sample was allowed to stand for 24 hours. Water was removed by drying the impregnated catalyst at $383 \mathrm{~K}$ for 2 hours. Subsequently the solid was heated at $653 \mathrm{~K}$ in air stream for 2.5 hours and then treated at $823 \mathrm{~K}$ for 4.5 hours. After this, samples were co-macerated at grain size of $0.053-0.105 \mathrm{~mm}$ and then were submitted to a pressure of 7.5 ton for $30 \mathrm{~min}$. Finally be sieved between grain sizes $0.84-1.19 \mathrm{~mm}$.

\subsection{Characterization.}

Alumina $\left(\gamma-\mathrm{Al}_{2} \mathrm{O}_{3}\right)$ and alumina impregnated with fluorine $\left(\gamma-\mathrm{Al}_{2} \mathrm{O}_{3} \mathrm{~F}_{\mathrm{x}}\right)$ were characterized by electrophoretic migration and potentiometric methods.

Electrophoretic migration measurements were carried out in a Zeta Meter 3.0 using $30 \mathrm{mg}$ of sample suspended in $300 \mathrm{~mL}$ of a KCl solution $10^{-3} \mathrm{~mol} \mathrm{~L}^{-1}$, as described previously ${ }^{27,28}$. Between each point the $\mathrm{pH}$ was adjusted with $\mathrm{HCl}$ or $\mathrm{NaOH} 0.1 \mathrm{~mol} \mathrm{~L}^{-1}$ as needed.

The surface acidities of the support and oxidized catalysts were measured 
by potentiometric titration with n-butylamine in acetonitrile using an $\mathrm{Ag} / \mathrm{AgCl}$ electrode, according to the experimental procedure described previously ${ }^{29}$.

\subsection{Reaction conditions.}

Prior to reaction, the catalysts were submitted to in situ sulphidation during $4 \mathrm{~h}$ at $623 \mathrm{~K}$ under a hydrogen pressure of $3 \mathrm{MPa}$, using a solution of $7 \% \mathrm{CS}_{2}$ in diesel. Identical conditions were used for single and stacked beds.

The determination of the catalytic activity in HDS was carried out as in previous studies ${ }^{4-11}$, in a stainless steel continuous flow micro-reactor, under operating conditions similar to what is used industrially. The total $\mathrm{H}_{2}$ pressure was $3 \mathrm{MPa}$, reaction temperatures were 598, 623 and $648 \mathrm{~K}$ using two types of feedstock, a first one, with $\sim 0.38 \% \mathrm{~S}$ (feed A) or a pre-treated feed with $\sim 0.02 \% \mathrm{~S}$ (feed B), at a flow of $30 \mathrm{~mL} \mathrm{~h}^{-1}$.

For single beds (catalysts or monometallic samples) $1 \mathrm{~g}$ of sample, either $\mathrm{Co} / \gamma-\mathrm{Al}_{2} \mathrm{O}_{3}$ or $\mathrm{Mo} / \gamma-\mathrm{Al}_{2} \mathrm{O}_{3}$, was placed in the center of the reactor. The bed of $\mathrm{Mo} / \gamma-\mathrm{Al}_{2} \mathrm{O}_{3}$ was diluted with $\mathrm{SiO}_{2}$ in a 1:1 (v/v) ratio. For the stacked bed systems, $1 \mathrm{~g}$ of $\mathrm{Co} / \gamma-\mathrm{Al}_{2} \mathrm{O}_{3}$ as Hso donor in the top or first bed was used, while $1 \mathrm{~g}$ of $\mathrm{Mo} / \gamma-\mathrm{Al}_{2} \mathrm{O}_{3}$ was placed in the third bed. This last bed was diluted with $\mathrm{SiO}_{2}$ 1:1 (v/v). The beds of $\mathrm{Co} / \gamma-\mathrm{Al}_{2} \mathrm{O}_{3}$ and $\mathrm{Mo} / \gamma-\mathrm{Al}_{2} \mathrm{O}_{3}$ were separated by a second bed, with the necessary amount of $\gamma-\mathrm{Al}_{2} \mathrm{O}_{3} \mathrm{~F}$ to have $3 \mathrm{~mm}$ of separation; this is called stacked beds. For both type of bed, the remaining space in the reactor was filled with $\mathrm{SiC}$ particles ${ }^{4-11}$.

Identical reaction conditions were used for single or stacked beds. Under each reaction condition, three samples of the reaction product were collected at intervals of $30 \mathrm{~min}$. between each reaction temperature other two "samples" are depreciates at intervals of $30 \mathrm{~min}$. Consequently, the time to complete each experiment at the three temperatures was slightly higher than 8 hours 9 .

\subsection{Activity determination.}

For feed $\mathrm{A}$, the determination of sulphur content of the samples before and after the reaction was carried out using a LECO S-144DR sulphur analyzer with an infrared detector; the $\mathrm{S}$ analysis has a lower error near to $1 \%$.

The feed B were characterized by gas chromatography, in a Shimadzu GC2010 equipped with a flame photometric detector (GC-FPD) operating at 573 $\mathrm{K}$, using $\mathrm{N}_{2}$ as carrier gas at a flow of $1.5 \mathrm{~mL} \mathrm{~min}^{-1}$ in a SPB-5 capillary column, with a heating program from $323 \mathrm{~K}$ to $573 \mathrm{~K}$ at $5 \mathrm{~K} \mathrm{~min}^{-1}$ and an injection of a sample of $1 \mu \mathrm{L}$ at $573 \mathrm{~K}$ using autosampler. The identification of sulphur containing compounds in the feed $\mathrm{B}$ was performed by doping the diesel with the standard probe molecules DBT and 4,6-DMDBT, and subsequently comparing the retention times obtained for other molecules with literature data ${ }^{30}$. The degree of conversion of the refractory molecules was estimated from the obtained peak areas by chromatographic analysis.

The HDS of these molecules occurs mainly by means of a hydrogenation mechanism. Thus, hydrogenated intermediates are formed ${ }^{31-33}$, and consequently chromatography conversion instead HDS is reported. Taking to account that HDS of DBT and 4,6-DMDBT molecules were carry out in a real matrix, and not in artificial mixture, this can be called "HDS in situ".

The synergism in the each staked bed systems was expressed as spillover factor (Fso) and defined as Fso = [HDS (\%) of the staked bed separated by $\gamma$ - $\mathrm{Al}_{2} \mathrm{O}_{3} \mathrm{~F}_{\mathrm{x}}$ particles / $\mathrm{HDS}(\%)$ of $\mathrm{Mo} / \gamma-\mathrm{Al}_{2} \mathrm{O}_{3}$ single bed].

\section{RESULTS AND DISCUSSIONS}

\subsection{Catalytic activity for feed $A$.}

Table 1 shows HDS activity results using feed A, by placing samples $\gamma-\mathrm{Al}_{2} \mathrm{O}_{3} \mathrm{~F}_{\mathrm{x}}$ with fluorine content from 0 to $2.5 \%$, as separator in the stacked-bed systems like $\mathrm{Co} / \gamma-\mathrm{Al}_{2} \mathrm{O}_{3} / / \gamma-\mathrm{Al}_{2} \mathrm{O}_{3} \mathrm{~F} / / \mathrm{Mo} / \gamma-\mathrm{Al}_{2} \mathrm{O}_{3}(\mathrm{x}=0.0,0.2,0.8,1.5$ or $2.5 \%$ of fluorine) at 598, 623 and $648 \mathrm{~K}$.

Table 1 show firstly, that $\mathrm{Co} / \gamma-\mathrm{Al}_{2} \mathrm{O}_{3}$ catalyst is not active in the HDS under reaction conditions used (Test 1). Moreover, show that the differences between $\mathrm{HDS}$ activity of $\mathrm{Mo} / \gamma-\mathrm{Al}_{2} \mathrm{O}_{3}$ and $\gamma-\mathrm{Al}_{2} \mathrm{O}_{3} \mathrm{~F} / / \mathrm{Mo} / \gamma-\mathrm{Al}_{2} \mathrm{O}_{3}$ bed are within the experimental error (Test 2 and Test 3), indicating that $\gamma-\mathrm{Al}_{2} \mathrm{O}_{3} \mathrm{~F}_{15}$ bed do not promote the activity of $\mathrm{Mo} / \gamma-\mathrm{Al}_{2} \mathrm{O}_{3}$ catalyst. Therefore, the increases in activity shown in Tests 4 to 8 of Table 1 must not be attributed to a promotion effect by $\gamma-\mathrm{Al}_{2} \mathrm{O}_{3} \mathrm{~F}$ bed. In addition, it is important to note in Table 1 that the activity of all $\mathrm{Co} / / \mathrm{Mo}$ systems is greater than the $\mathrm{Mo} / \gamma-\mathrm{Al}_{2} \mathrm{O}_{3}$ catalyst activity (Table 1, Test 2), suggesting that a synergism via Hso is observed, in all range of fluorine contents studied.

The results of Table 1 shown moreover that the HDS activity of $\mathrm{Co} / \mathrm{Mo}$ system increases with increasing fluorine content, suggesting that fluorine favors the Hso migration, similarly as occurs with phosphorous ${ }^{11}$. Promotion effect could be explained from the influence of fluorine on neighboring bonds, due to its high electronegativity, favoring Hso transport through the surface of $\gamma-\mathrm{Al}_{2} \mathrm{O}_{3} \mathrm{~F}_{x}{ }^{34}$. For fluorine contents among 0.2 to $0.8 \%$ fluorine replaces $\mathrm{OH}$ groups weakening the close $\mathrm{O}-\mathrm{H}$ bonds, reaching a maximum at concentration of fluorine near to $0.8 \%$.

Table 1: Catalytic activity in $\mathrm{HDS}(\%)$ of $\mathrm{Co} / \gamma-\mathrm{Al}_{2} \mathrm{O}_{3}, \mathrm{Mo} / \gamma-\mathrm{Al}_{2} \mathrm{O}_{3}$ and $\mathrm{Co} / / \gamma-\mathrm{Al}_{2} \mathrm{O}_{3} \mathrm{~F}_{\mathrm{x}} / / \mathrm{Mo}$ stacked-bed systems used samples of $\gamma-\mathrm{Al}_{2} \mathrm{O}_{3} \mathrm{~F}_{\mathrm{x}}$ with different fluorine content as separator, at different reaction temperatures.

\begin{tabular}{|c|c|c|c|c|}
\hline \multirow{2}{*}{ Test } & \multirow{2}{*}{$\mathrm{Bed}$} & \multicolumn{3}{|c|}{$\mathrm{HDS}(\%)$} \\
\cline { 3 - 5 } & & $598 \mathrm{~K}$ & $623 \mathrm{~K}$ & $648 \mathrm{~K}$ \\
\hline 1 & $\mathrm{Co} / \gamma-\mathrm{Al}_{2} \mathrm{O}_{3}(\mathrm{Co})$ & 0.0 & 0.0 & 0.0 \\
\hline 2 & $\mathrm{Mo} / \gamma-\mathrm{Al}_{2} \mathrm{O}_{3}(\mathrm{Mo})$ & 4.0 & 8.9 & 18.5 \\
\hline 3 & $\gamma-\mathrm{Al}_{2} \mathrm{O}_{3} \mathrm{~F}_{1.5} / / \mathrm{Mo}$ & 3.7 & 8.6 & 18.3 \\
\hline 4 & $\mathrm{Co} / / \gamma-\mathrm{Al}_{2} \mathrm{O}_{3} \mathrm{~F}_{0.0} / / \mathrm{Mo}$ & 5.9 & 11.2 & 20.9 \\
\hline 5 & $\mathrm{Co} / / \gamma-\mathrm{Al}_{2} \mathrm{O}_{3} \mathrm{~F}_{0.2} / \mathrm{Mo}$ & 6.7 & 12.1 & 21.7 \\
\hline 6 & $\mathrm{Co} / / \gamma-\mathrm{Al}_{2} \mathrm{O}_{3} \mathrm{~F}_{0.8} / / \mathrm{Mo}$ & 8.4 & 14.6 & 24.0 \\
\hline 7 & $\mathrm{Co} / / \gamma-\mathrm{Al}_{2} \mathrm{O}_{3} \mathrm{~F}_{1.5} / \mathrm{Mo}$ & 6.8 & 12.8 & 22.8 \\
\hline 8 & $\mathrm{Co} / / \gamma-\mathrm{Al}_{2} \mathrm{O}_{3} \mathrm{~F}_{2.5} / \mathrm{Mo}$ & 5.5 & 11.2 & 20.1 \\
\hline
\end{tabular}

The Figure 1 shows that acidity increases until content near to $0.8 \%$, in close agreement with the idea that fluorine replace partially the $\mathrm{OH}$ groups on the alumina surface. This replacement leads to a positive effect on their surface acidity by making more labile the $\mathrm{O}-\mathrm{H}$ bonds, facilitating consequentially the migration of Hso. By increasing the fluorine content higher than $0.8 \%$, would replace a greater amount of $\mathrm{OH}$ groups without causing an effect on the surface acidity, but only decreasing the number of $\mathrm{OH}$ sites where the Hso may migrate. Certainly, a similar trend is seen in Figure 2, where the synergism expressed as spillover factor (Fso) increases at fluorine content near to $0.8 \%$, and at higher $\mathrm{F}$ content the synergism decrease. Figure 2 also shows finally that Fso decrease with reaction temperature in close agreement with results obtained previously ${ }^{4-11}$.

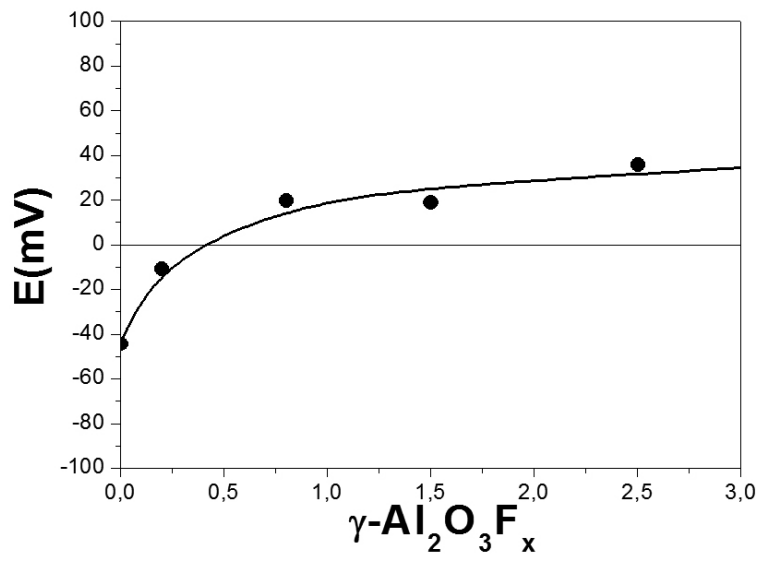

Figure 1: Variation of the total acidity of $\gamma-\mathrm{Al}_{2} \mathrm{O}_{3} \mathrm{~F}_{x}$ samples, with the fluorine content.

\subsection{Interaction scheme proposed Al-F.}

In Figure 3 it is shown a scheme of $\gamma-\mathrm{Al}_{2} \mathrm{O}_{3} \mathrm{~F}_{\mathrm{x}}$ with different fluorine content on the alumina surface, which acts as separator in the stacked beds used in this study. Without the incorporation of fluorine the alumina surface has an amount of $\mathrm{OH}$ groups available for Hso migration, as well as some type Al-O-Al bonds (A). By incorporating fluorine scheme proposes an increase in the number of $\mathrm{OH}$ sites available for Hso migration, caused either by the breaking of bonds Al-O-Al, to incorporate fluoride ions ${ }^{34}$. Taking into account that fluorine replaced $\mathrm{OH}$ groups, causing weakening of neighbor $\mathrm{O}-\mathrm{H}$ bond, and favoring transport of Hso through the surface (B). This effect will be more notorious increasing fluorine content $(\mathrm{C})$, which shows the greatest number of available $\mathrm{OH}$ groups on the surface with weakest bonds by presence of fluorine. At higher fluorine content (D) ceases to be optimal, and begins to favor a lesser proportion Hso migration across the surface. This behavior suggests that the amount of available $\mathrm{OH}$ groups through their replacement, have a significant influence on the neighboring $\mathrm{O}-\mathrm{H}$ bonds since they lose proximity. 


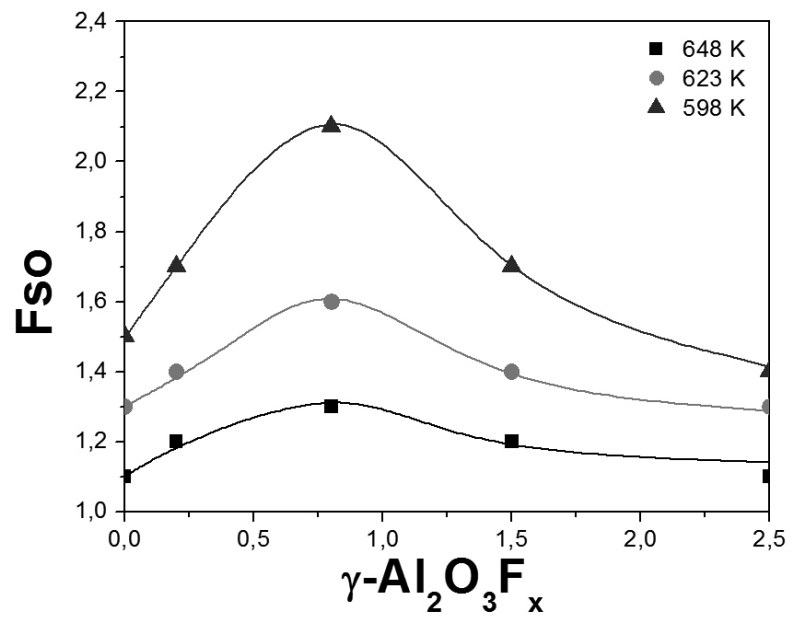

Figure 2: Spillover factor (Fso) of $\mathrm{Co} / / \gamma-\mathrm{Al}_{2} \mathrm{O}_{3} \mathrm{~F}_{\mathrm{x}} / / \mathrm{Mo}$ stacked-bed systems used samples of $\gamma-\mathrm{Al}_{2} \mathrm{O}_{3} \mathrm{Fx}$ with different fluorine content as separator.
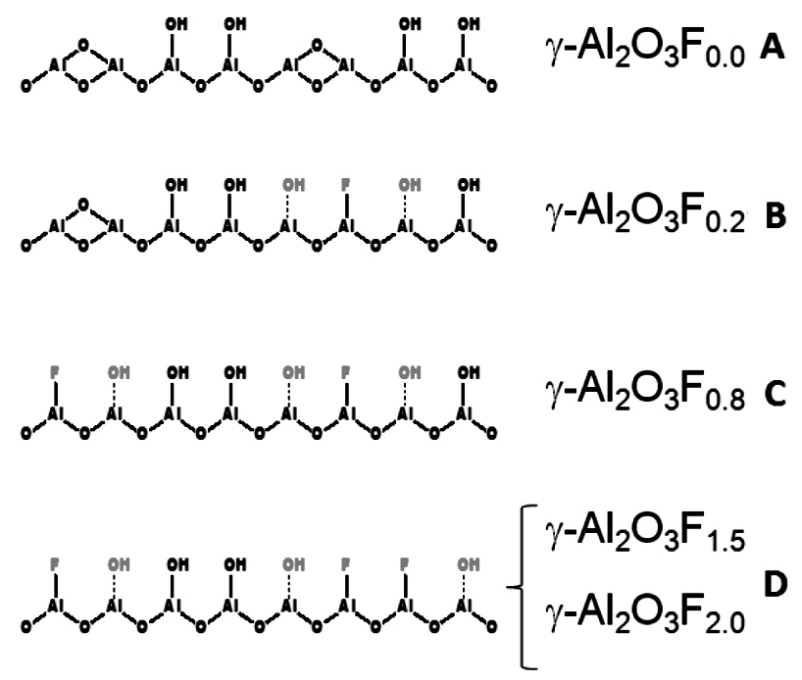

Figure 3: Scheme of varying amount of acid surface sites with the fluorine content in $\gamma-\mathrm{Al}_{2} \mathrm{O}_{3} \mathrm{~F}_{\mathrm{x}}$ samples.

This scheme is in agreement with previous studies ${ }^{34-37}$ that indicates that the way in which fluorine ions interacts with the alumina, is replacing the hydroxyl groups present on their surface, preferably $\mathrm{OH}$ groups with lower net charge, i.e. most basic $\mathrm{OH}$ groups ${ }^{38}$. Considering that in the $\gamma-\mathrm{Al}_{2} \mathrm{O}_{3}$ approximately $15 \%$ of the hydroxyl groups present are basic ${ }^{36,37}$, it is assumed that fluorine has high probability of being deposited replacing these basic $\mathrm{OH}$ groups on its surface. As noted, the presence of surface $\mathrm{OH}$ groups is a prerequisite for the Hso migrate across a surface, since the migration mechanism is through acidic surfaces ${ }^{34}$. For this reason, the fluorine to replace the surface $\mathrm{OH}$ groups, would be a hindrance to the Hso migration, and this would result in a decrease the HDS activity of the catalyst system when increase the fluorine content in the separator. However, this phenomenon is not experimentally observed, as discussed below. Electrophoretic characterization of $\gamma-\mathrm{Al}_{2} \mathrm{O}_{3} \mathrm{~F}_{\mathrm{x}}$ show in Table 2 that Zero point of charge (ZPC) decreases to add fluorine to the alumina, in agreement with fluorine replacing $\mathrm{OH}$ groups, and in close agreement with the scheme suggested in Figure 3. It is important to mention that there is not a direct relationship between the Hso promotion and ZPC, rather the ZPC is a sign that surface $\mathrm{OH}$ groups are being replaced by $\mathrm{F}$ atoms, with a greater electronegativity. Unfortunately the technique is not suitable to detect the presence of activated $\mathrm{OH}$ groups by $\mathrm{F}$, which also decrease in quantity from certain content of $\mathrm{F}$.
Table 2: Zero point of charge (ZPC) of $\gamma-\mathrm{Al}_{2} \mathrm{O}_{3} \mathrm{~F}_{x}$ samples, with different fluorine content.

\begin{tabular}{|c|c|}
\hline Samples $\left(\gamma-\mathrm{Al}_{2} \mathbf{O}_{\mathbf{3}} \mathbf{F}_{\mathbf{X}}\right)$ & ZPC $(\mathbf{p H})$ \\
\hline$\gamma-\mathrm{Al}_{2} \mathrm{O}_{3} \mathrm{~F}_{0.0}$ & 8.48 \\
\hline$\gamma-\mathrm{Al}_{2} \mathrm{O}_{3} \mathrm{~F}_{0.2}$ & 8.47 \\
\hline$\gamma-\mathrm{Al}_{2} \mathrm{O}_{3} \mathrm{~F}_{0.8}$ & 8.39 \\
\hline$\gamma-\mathrm{Al}_{2} \mathrm{O}_{3} \mathrm{~F}_{1.5}$ & 8.22 \\
\hline$\gamma-\mathrm{Al}_{2} \mathrm{O}_{3} \mathrm{~F}_{2.5}$ & 8.00 \\
\hline
\end{tabular}

3.3. "HDS in situ" of refractory molecules present in the feed B.

As was pointed in this manuscript the HDS can been called "in situ" to differentiate these to other studies that could be made with artificial mixtures of these model compounds ${ }^{9}$. We have studied two refractory molecules with different steric hindrance i.e. different refractory degree: 4-MDBT and 4,6-DMDBT. In the samples obtained using feed B, were not detected a peak different from those observed in the original feed, suggesting that the hydrodesulphurization reaction of these two molecules do not leads to reaction intermediates containing sulphur. Consequently, it is possible to calculate the HDS of each molecule from the decrease of peak area associated, obtained by chromatographic analysis.

Table 3 shows firstly the conversion of 4-MDBT and 4,6-DMDBT at 598 $\mathrm{K}$, of $\mathrm{Co} / \gamma-\mathrm{Al}_{2} \mathrm{O}_{3}$ and $\mathrm{Mo} / \gamma-\mathrm{Al}_{2} \mathrm{O}_{3}$ single beds and $\mathrm{Co} / \gamma-\mathrm{Al}_{2} \mathrm{O}_{3} / / \gamma-\mathrm{Al}_{2} \mathrm{O}_{3} \mathrm{~F} / /$ $\mathrm{Mo} / \gamma-\mathrm{Al}_{2} \mathrm{O}_{3}$ stacked bed. As is usual in these reaction conditions the $\mathrm{Co} / \gamma$ $\mathrm{Al}_{2} \mathrm{O}_{3}$ shows no activity, while that $\mathrm{Mo} / \gamma-\mathrm{Al}_{2} \mathrm{O}_{3}$ is active. As we expected, the systems $\mathrm{Co} / \gamma-\mathrm{Al}_{2} \mathrm{O}_{3} / / \gamma-\mathrm{Al}_{2} \mathrm{O}_{3} \mathrm{~F} / / \mathrm{Mo} / \gamma-\mathrm{Al}_{2} \mathrm{O}_{3}$ are more active than $\mathrm{Mo} / \gamma-\mathrm{Al}_{2} \mathrm{O}_{3}$ or $\mathrm{Co} / \gamma-\mathrm{Al}_{2} \mathrm{O}_{3} / / \gamma-\mathrm{Al}_{2} \mathrm{O}_{3} / / \mathrm{Mo} / \gamma-\mathrm{Al}_{2} \mathrm{O}_{3}$ systems. Differences in conversion of 4-MDBT and 4,6-DMDBT can be related with the amount and position of the substituent in close agreement with previous studies ${ }^{9}$, is observed that the HDS is higher for the less refractory molecules: 4-MDBT than 4,6-DMDBT.

In Co//Mo staked bed there are no Co-Mo-S phase therefore Co//Mo synergism must be attributed only by Hso. Considering that Hso favors HDS Co// Mo synergism by HYD pathway ${ }^{7}$ and that the presence of fluorine in the separator beds improves the Hso migration, it is clear that staked bed would favor the HDS of refractory molecules. This is seen more clearly in Figure 4 which shows the dependence of Fso with fluorine content at $598 \mathrm{~K}$ for the conversion of both molecules. Higher values of Fso are observed for the most refractory molecule 4,6-DMDBT > 4-MDBT. It is also noted that the fluorine content exhibits the same trend observed for feed A, (presenting a maximum near to $0.8 \%$ of fluorine) must be a general behavior for all sulphur molecules in staked bed system.

Table 3: HDS Conversion (\%) in situ of 4-MDBT and 4,6-DMDBT of $\mathrm{Co} / \gamma-\mathrm{Al}_{2} \mathrm{O}_{3}, \mathrm{Mo} / \gamma-\mathrm{Al}_{2} \mathrm{O}_{3}$ and $\mathrm{Co} / / \gamma-\mathrm{Al} 2 \mathrm{O} 3 \mathrm{Fx} / / \mathrm{Mo}$ stacked-bed systems using samples of $\gamma-\mathrm{Al}_{2} \mathrm{O}_{3} \mathrm{~F}_{\mathrm{x}}$ with different fluorine content as separator, at $598 \mathrm{~K}$.

\begin{tabular}{|c|c|c|c|}
\hline \multirow{2}{*}{ Test } & \multirow{2}{*}{$\mathrm{Bed}$} & \multicolumn{2}{|c|}{$\mathrm{HDS}(\%)$} \\
\cline { 3 - 4 } & & \multirow{2}{*}{ 4-MDBT } & 4,6-DMDBT \\
\hline 1 & $\mathrm{Co} / \gamma-\mathrm{Al}_{2} \mathrm{O}_{3}(\mathrm{Co})$ & 0.0 & 0.0 \\
\hline 2 & $\mathrm{Mo} / \gamma-\mathrm{Al}_{2} \mathrm{O}_{3}(\mathrm{Mo})$ & 12.6 & 6.3 \\
\hline 4 & $\mathrm{Co} / / \gamma-\mathrm{Al}_{2} \mathrm{O}_{3} \mathrm{~F}_{0.0} / \mathrm{Mo}$ & 23.6 & 17.9 \\
\hline 5 & $\mathrm{Co} / / \gamma-\mathrm{Al}_{2} \mathrm{O}_{3} \mathrm{~F}_{0.2} / \mathrm{Mo}$ & 26.8 & 21.9 \\
\hline 6 & $\mathrm{Co} / / \gamma-\mathrm{Al}_{2} \mathrm{O}_{3} \mathrm{~F}_{0.8} / \mathrm{Mo}$ & 44.9 & 41.9 \\
\hline 7 & $\mathrm{Co} / / \gamma-\mathrm{Al}_{2} \mathrm{O}_{3} \mathrm{~F}_{1.5} / \mathrm{Mo}$ & 35.4 & 31.3 \\
\hline 8 & $\mathrm{Co} / / \gamma-\mathrm{Al}_{2} \mathrm{O}_{3} \mathrm{~F}_{2.5} / / \mathrm{Mo}$ & 31.0 & 26.5 \\
\hline
\end{tabular}




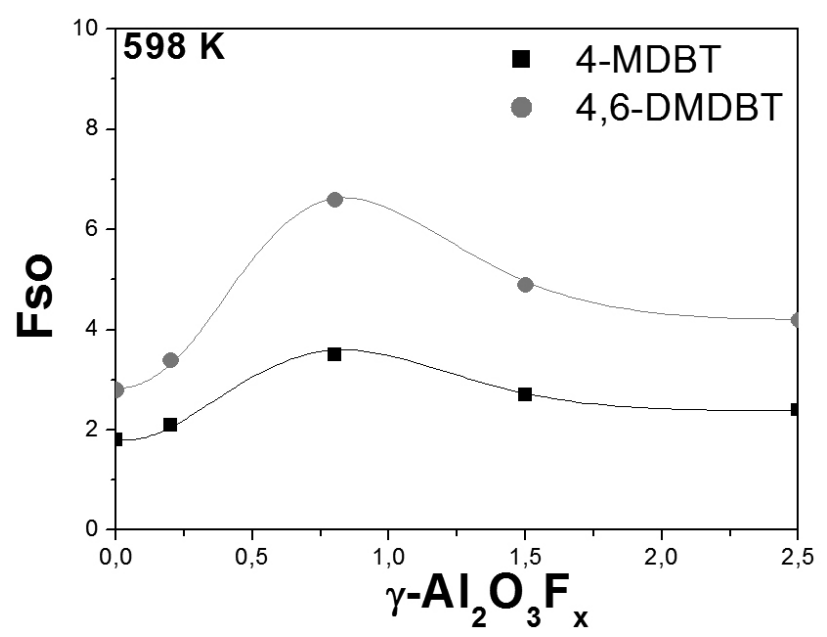

Figure 4: Spillover factor (Fso) for 4-MDBT $(\bullet)$ and 4,6-DMDBT $(\bullet)$ of $\mathrm{Co} / / \gamma-\mathrm{Al}_{2} \mathrm{O}_{3} \mathrm{~F}_{x} / / \mathrm{Mo}$ stacked-bed systems using samples of $\gamma-\mathrm{Al}_{2} \mathrm{O}_{3} \mathrm{~F}_{\mathrm{x}}$ with different fluorine content at $598 \mathrm{~K}$

\section{CONCLUSIONS}

Synergism for $\mathrm{Co} / / \gamma-\mathrm{Al}_{2} \mathrm{O}_{3} \mathrm{~F}_{\mathrm{x}} / / \mathrm{Mo}$ staked bed reaches a maximum at $\mathrm{X}=$ $0.8 \%$ because $\mathrm{Al}-\mathrm{F}$ groups produce a weakening of neighbor $\mathrm{OH}$ bond. Moreover this synergism increases when the molecule is more refractory: 4,6-DMDBT > 4-MDBT. Thus, the synergism reported in bimetallic Co-Mo catalysts contain fluoride systems, can be well explained from Hso and improving their migration through the support surface. Results obtained with staked bed suggest that the addition of fluorine in Co-Mo bimetallic HDS catalysts might be a good tool for the hydrodesulphurization of feed from deeper layers, because it would increase the activity and selectivity of the most refractory molecules.

\section{ACKNOWLEDGMENTS}

The authors wish to thank: FONDECYT Project No 1095120 and 1130749 , PUCV DI 127.760, ENAP.

\section{REFERENCES}

1. S.A. Ali, S. Ahmed, K.W. Ahmed, M.A. Al-Saleh, Fuel Processing Tech., 98, 39, (2012).

2. H. Topsoe, B.S. Clausen, F.E. Massoth, in: J.R. Anderson, M. Boudard (Eds.), Catalysis, Science and Technology, vol. 11, Springer, Berlin, 1996.

3. B. Delmon, G. Froment, Catal. Rev. Sci. Eng., 38, 69, (1996).

4. J. Ojeda, N. Escalona, P. Baeza, M. Escudey, F.J. Gil-Llambías, Chem. Commun., 13, 1608, (2003).
5. P. Baeza, M.S. Ureta-Zañartu, N. Escalona, J. Ojeda, F.J. Gil-Llambías, B. Delmon, Appl. Catal., 274, 303, (2004).

6. P. Baeza, M. Villarroel, P. Ávila, A. López Agudo, B. Delmon, F.J. Gil Llambías, Appl. Catal., 304, 109, (2006).

7. N. Escalona, R. García, G. Lagos, C. Navarrete, P. Baeza, F.J. Gil-Llambías, Catal. Commun., 7, 1053, (2006).

8. M. Villarroel, P. Baeza and F. J. Gil-Llambías, J. Chil. Chem. Soc. 55, № 4, 283, (2010).

9. M. Villarroel, E. Camú, N. Escalona, P. Ávila, S.B. Rasmussen, P. Baeza, F. Gil-Llambías, Appl. Catal., 399, 63, (2011).

10. M. Villarroel, A. Méndez, G. Águila, N. Escalona, P. Baeza, F. Gil-Llambías, Catal. Today, 156, 65, (2010).

11. M. Villarroel, P. Baeza, F. Gracia, N. Escalona, P. Ávila, F.J. Gil-Llambias, Appl. Catal., 364, 75, (2009).

12. M. Zdrazil, Catal. Today, 3, 269, (1988).

13. G. Muralidhar, F.E. Massoth, J. Shabtai, J. Catal., 85, 44, (1984).14. J. Miciukiewicz, Q. Qader y F.E. Massoth, Appl. Catal., 49, 247, (1989).

15. Y. Okamoto, T. Imanaka, J. Phys. Chem., 92, 7102, (1988).

16. Y. Okamoto, A. Maezawa, M. Kitamura, L. Toshinobu, Appl. Catal., 55, 215, (1989).

17. Ch. Papadopoulou, Ch. Kordulis, A. Lycourghiotis, React. Kinet. Catal. Letter, 33, 259, (1987).

18. Ch. Papadopoulou, A. Lycourghiotis, P. Grange, B. Delmon, Appl. Catal., 38, 255, (1988)

19. H.K. Matralis, A. Lycourghiotis, P. Grange, B. Delmon, Appl. Catal., 38, 273, (1988).

20. J. Ramírez, R. Cuevas, A. López Agudo, S. Mendioroz, J.L.G. Fierro, Appl. Catal., 57, 223, (1990).

21. J.L.G. Fierro, R. Cuevas, J. Ramírez, A. López Agudo, Bull. Soc. Chem. Belg., 100, 945, (1991).

22. C. Kwak, J.J. Lee, J.S. Bae, K. Choi, S.Moon, Appl. Catal., 200, 233, (2000).

23. H. Kim, J.J. Lee, J. H. Koh, S. Moon, Appl. Catal., 50, 17, (2004).

24. A. Stanislaus, A. Marafi, M.S. Rana, Catal. Today, 153, 1, (2010).

25. S. Bej, S. Maity, U. Turaga, Energy Fuels, 18, 1227, (2004).

26. J. Ramírez, R. Cuevas, Appl. Catal., 57, 223, (1990).

27. M. Escudey, F.J. Gil Llambías, J. Colloid Interf. Sci., 107, 272, (1985).

28. N. Escalona, J. Ojeda, R. Cid, G. Alves, A. López Agudo, J.L.G. Fierro, F.J. Gil-Llambías, Appl. Catal., 234, 45, (2002).

29. R. Cid, G. Pecchi, Appl. Catal., 14, 15, (1985).

30. X. Ma, L. Sun, C. Song, Catal. Today, 77, 107, (2002).

31. X. Li, A. Wang, M. Egorova, R. Prins, J. Catal., 250, 283, (2007).

32. H. Wang, R. Prins, J. Catal., 258, 153, (2008).

33. Y. Sun, R. Prins, J. Catal., 267, 193, (2009).

34. D. Martin, D. Duprez, J. Phys. Chem. B, 101, 4428, (1997).

35. M. Sun, R. Prins, J. Catal., 201, 138, (2001).

36. H. Knözinger, P. Ratnasamy, Catal. Rev.-Sci. Eng., 17, 31, (1978).

37. A.A. Tsyganenko, P.P. Mardilovich, J. Chem. Soc., Faraday Trans., 92, 4843, (1996)

38. M. Sun, D. Nicosia, R. Prins, Catal. Today, 86, 173, (2003). 